\title{
PENINGKATAN HASIL BELAJAR IPA DENGAN MEDIA KARTU TEMPEL PADA SUBTEMA BAGAIMANA TUBUH MENGOLAH MAKANAN KELAS V SISWA SEKOLAH DASAR
}

\author{
Cahyaningtyas Dewi Nurani \\ IKIP PGRI WATES \\ Email: cahyaningtyasdn@gmail.com
}

\begin{abstract}
Abstrak. Penelitian ini bertujuan untuk meningkatkan hasil belajar IPA dengan Media Kartu Tempel pada subtema Bagaimana Tubuh Mengolah Makanan pada peserta didik kelas V Sekolah Dasar Negeri Kasatriyan Tahun Pelajaran 2019/2020. Jenis penelitian yaitu Penelitian Tindakan Kelas (PTK), dengan rancangan Kemmis \& Mc. Subjek pada PTK ini adalah peserta didik kelas V Sekolah Dasar Negeri Kasatriyan yang berjumlah 15. Metode pengumpulan data menggunakan tes dan observasi. Teknik analisis data menggunakan deskriptif kualitatif dan kuantitatif. Hasil penelitian menunjukkan bahwa terjadi peningkatan hasil belajar peserta didik pada mata pelajaran IPA. Sebelum dilakukan tindakan terdapat 3 peserta didik yang mencapai ketuntasan belajar (20\%) dan 12 peserta didik belum mencapai ketuntasan (80\%). Setelah dilakukan tindakan siklus I peserta didik yang mencapai ketuntasan belajar sebanyak 10 peserta didik (67\%). Pada siklus II, peserta didik yang mencapai ketuntasan belajar sebanyak 13 peserta didik $(87 \%)$.
\end{abstract}

Kata kunci: Hasil Belajar, Media Kartu Tempel, Ilmu Pengetahuan Alam

\section{PENDAHULUAN}

Pendidikan yang berkualitas adalah pendidikan yang mampu mengantar peserta didik mencapai tujuan pembelajaran. Kegiatan proses belajar mengajar tidak lepas dari berbagai strategi, metode, model, bahkan sumber belajar maupun media yang digunakan guru agar peserta didik dapat belajar secara efektif dan efisien, serta mengena dengan apa yang menjadi tujuan kegiatan belajar mengajar tersebut. Media pembelajaran mempunyai peranan yang penting dalam proses kegiatan pembelajaran. Menurut Degeng (Wena, 2011: 9) media pembelajaran adalah komponen strategi penyampaian yang dapat dimuati pesan yang akan disampaikan kepada peserta didik, baik berupa orang, alat, maupun bahan. Media yang digunakan guru harus sesuai dengan tujuan pembelajaran yang telah ditetapkan sehingga mampu merangsang dan menumbuhkan minat peserta didik dalam belajar. Dengan demikian, akan tumbuh interaksi antara media pembelajaran dan peserta didik dalam belajar. Adanya interaksi positif antara media pembelajaran dan peserta didik pada akhirnya akan mampu mempercepat proses pemahaman peserta didik terhadap isi pembelajaran.

Berdasarkan hasil observasi dan wawancara dengan guru kelas V SD 
Negeri Kasatriyan, diperoleh fakta dalam pembelajaran IPA di kelas $\mathrm{V}$ pada tema makanan sehat subtema bagaimana tubuh menolah makanan materi organ pencernaan merupakan salah satu materi yang susah dipahami oleh peserta didik. Peserta didik sulit menghafal urutan organ pencernaan dan menghafal materi, hal ini terjadi karena guru sulit menemukan media pembelajaran yang tepat. Selain itu, pemanfaatan media pembelajaran yang ada di sekolah sangatlah minim. Keterbatasan waktu dalam membuat media juga menjadi salah satu faktor yang berpengaruh terhadap minimnya pemanfaatan media dalam proses pembelajaran. Minimnya pemanfaatan media karena keterbatasan waktu sehingga guru lebih memilih mengajar peserta didik tanpa menggunakan media pembelajaran. Hal tersebut menjadikan peserta didik pasif dalam menerima materi IPA yaitu peserta didik hanya duduk memperhatikan, mendengar, mencatat, dan menghafal materi yang disampaikan guru. Sehingga peserta didik mudah lupa terhadap materi pembelajaran yang telah dipelajari karena hanya menghafal, tidak secara langsung mengamati media yang sesuai dengan materi pembelajaran. Hal tersebut menyebabkan hasil belajar peserta didik rendah, terlihat dari setengah jumlah peserta didik nilainya masih di bawah Kriteria Ketuntasan Minimal (KKM) yaitu 75.

Di tingkat sekolah dasar penggunaan media pembelajaran sebagai sumber belajar sangatlah dibutuhkan. Apalagi bagi anak usia sekolah dasar yang perkembangan berpikirnya masih memerlukan sesuatu yang kongkret, belum merambah pada hal-hal yang sifatnya abstrak, walaupun guru menyadari komponen-komponen pembelajaran juga mempunyai kelebihan maupun kelemahannya, seperti media kartu. Media kartu ini termasuk dalam media visual, media kartu salah satu media yang cukup efektif dan efisien diterapkan pada anak usia sekolah dasar yang berfungsi untuk menarik perhatian, memperjelas, dan mengilustrasikan materi pembelajaran.

Berdasarkan latar belakang masalah tersebut, maka peneliti tertarik untuk melakukan penelitian yang berjudul “Upaya Meningkatkan Hasil Belajar IPA dengan Media Kartu Tempel pada Tema 3 Subtema 1 Bagaimana Tubuh Mengolah Makanan pada Peserta Didik Kelas V SD Negeri Kasatriyan Tahun Pelajaran 2019/2020"

\section{LANDASAN TEORITIS}

\section{A. Hasil Belajar}

Hasil belajar diukur melalui bagaimana proses itu dilakukan, apakah sesuai dengan prosedur atau kaidah yang benar, bukan pada produk saat itu, karena proses yang benar, kelak akan menghasilkan sesuatu yang bermanfaat ketika kembali ke masyarakat sebagai outcome/ keluaran (Hosnan, 2014: 4). Menurut Anderson (Rusdiana, 2018: 189) penilaian hasil belajar pada ranah kognitif, meliputi: mengingat, memahami, menerapkan, menganalis, mengevaluasi dan mencipta.

Makna hasil belajar menurut Susanto (2013: 5) "hasil belajar merupakan perubahan-perubahan yang terjadi pada diri peserta didik, baik menyangkut aspek kognitif, afektif, dan psikomotor sebagai hasil 
dari kegiatan belajar". Dalam penelitian, peneliti menggunakan ranah kognitif yang menjadi objek penelitian hasil belajar. Berdasarkan permasalahan di lapangan yaitu peserta didik sulit untuk memahami materi, hal ini terjadi karena guru sulit menemukan media pembelajaran yang tepat. Peserta didik menjadi pasif dalam menerima materi, hanya duduk memperhatikan, mendengar, mencatat, dan menghafal materi yang disampaikan guru. Sehingga peserta didik mudah lupa terhadap materi pembelajaran. Hal tersebut menyebabkan hasil belajar peserta didik rendah di bawah KKM.

\section{B. Media Kartu Tempel}

Proses belajar mengajar ada dua unsur yang amat penting adalah metode mengajar dan media pembelajaran. Menurut Arsyad (2015: 3), kata media berasal dari bahasa Latin medius yang secara harfiah berarti 'tengah', 'perantara'. Menurut Hosnan (2014: 111), media pembelajaran merupakan sarana/ bentuk komunikasi nonpersonal (bukan manusia), sedangkan sarana tersebut merupakan wadah dari informasi pelajaran yang akan dikomunikasikan yang juga merupakan alat perantara yang bersifat menimbulkan daya tarik/perhatian peserta didik (student interest) dalam kegiatan belajar serta tujuan yang hendak dicapai, yaitu tercapainya komunikasi yang efektif.

Saptono (Masturi, dkk, 2014: 41) media kartu adalah kertas tebal yang berisi gambar-gambar atau tulisan tertentu yang dapat dimanfaatkan dalam

mengembang-kan pembelajaran IPA dan membantu pemahaman peserta didik tentang konsep tertentu. Media kartu tempel adalah sebuah alat atau media belajar yang di rancang oleh peneliti untuk membantu mempermudah belajar dalam pembelajaran tematik. Susilana dan Riyana (Jannah, Miftahul \& Hasmawati, 2017: 14) menjelaskan kelebihan media kartu bergambar, yaitu: mudah diingat, menyenangkan, praktis, dan mudah untuk dibawa.

C. Pembelajaran IPA

Aly \& Eny Rahma (2009: 18) bahwa "IPA adalah suatu pengetahuan teoritis yang diperoleh/disusun dengan cara yang khas/khusus, yaitu dengan melakukan observasi, eksperimentasi, penyimpulan, penyusunan teori, eksperimentasi, observasi, dan demikian seterusnya kait-mengkait antara cara yang satu dengan cara yang lain". Konsep dasar mata pelajaran IPA yaitu mata pelajaran yang dikembangkan dengan memperhatikan ketercapaian terhadap aspek pengetahuan, sikap dan keterampilan melalui proses pengamatan dan berpikir secara logis serta sistematis untuk memahami segala bentuk kejadian yang berada di alam semesta beserta isinya.

Penelitian ini mengambil materi organ pencernaan hewan dan manusia pada tema makanan sehat subtema bagaimana tubuh mengolah makanan dalam pembelajaran 1 dan 2. Sistem pencernaan pada hewan adalah Rumen $\rightarrow$ Retikulum $\rightarrow$ Omasum $\rightarrow$ Abomasum. Sistem 
pencernaan manusia adalah Mulut $\rightarrow$ Kerongkongan $\rightarrow$ Lambung $\rightarrow$ Usus Halus $\rightarrow$ Usus Besar $\rightarrow$ Anus.

\section{METODE}

Pendekatan penelitian yang digunakan adalah Penelitian Tindakan Kelas (PTK) atau Classroom Action Research. Menurut Daryanto (2011: 4) penelitian tindakan kelas adalah penelitian yang dilakukan oleh guru di dalam kelasnya sendiri melalui refleksi diri dengan tujuan untuk memperbaiki kualitas proses pembelajaran di kelas sehingga hasil belajar peserta didik meningkat. Subjek dalam penelitian ini adalah peserta didik kelas $\mathrm{V}$ Sekolah Dasar Negeri Kasatriyan tahun pelajaran 2019/2020. Kelas V berjumlah 15 peserta didik, terdiri dari 10 peserta didik laki-laki dan 5 peserta didik perempuan.

Penelitian tindakan dibagi menjadi beberapa tahapan yaitu perencanaan (planning), tindakan (action), observasi (observe), serta refleksi (reflect). Model penelitian tindakan kelas yang akan digunakan dalam penelitian ini adalah menggunakan model Kemmis dan Mc Taggart. Teknik pengumpulan data menggunakan tes dan observasi. Instrumen yang digunakan adalah soal tes dan lembar observasi. Uji validitas instrumen menggunakan validitas isi (expert judgement).

Keabsahan data menggunakan triangulasi metode peneliti mengecek keabsahan data dari sumber yang sama melalui observasi dan tes analisis sehingga menghasilkan kesimpulan yang baik dan benar. Dalam menganalisis data pada penelitian ini peneliti menggunakan teknik kuantitatif dan teknik kualitatif. Teknik kuantitatif bertujuan untuk memperoleh data peningkatan hasil belajar peserta didik dan teknik kualitatif bertujuan untuk memperoleh data observasi aktivitas guru saat mengajar dan aktivitas peserta didik yang digunakan untuk menentukan peningkatan kegiatan pembelajaran khususnya berbagai tindakan yang telah dilakukan saat kegiatan pembelajaran. Penelitian ini dikatakan berhasil apabila peningkatan hasil belajar peserta didik hingga $75 \%$ peserta didik di kelas memenuhi kriteria ketuntasan minimal yakni $\geq 75$.

\section{HASIL DAN PEMBAHASAN}

Hasil penelitian variabel hasil belajar IPA diperoleh data sebagai berikut:

\begin{tabular}{|l|c|c|c|c|}
\hline Siklus & $\begin{array}{c}\text { Jumlah } \\
\text { Peserta } \\
\text { Didik }\end{array}$ & $\begin{array}{c}\text { Nilai } \\
\text { rata- } \\
\text { rata }\end{array}$ & Tuntas & Persentase \\
\hline Pretest & 15 & 66 & 5 & $33 \%$ \\
\hline Siklus I & 15 & 77 & 10 & $67 \%$ \\
\hline Siklus II & 15 & 82,67 & 13 & $87 \%$ \\
\hline
\end{tabular}

Hasil observasi aktivitas mengajar dan aktivitas peserta didik pada Siklus I diperolah data sebagai berikut:

\begin{tabular}{|l|c|c|}
\hline \multicolumn{1}{|c|}{ Hasil } & $\begin{array}{c}\text { Observasi } \\
\text { Aktivitas } \\
\text { Mengajar }\end{array}$ & $\begin{array}{c}\text { Aktivitas } \\
\text { Peserta Didik }\end{array}$ \\
\hline Pertemuan 1 & $70 \%$ & $71,67 \%$ \\
\hline Pertemuan 2 & $75 \%$ & $76,67 \%$ \\
\hline Persentase & $\mathbf{7 2 , 5 \%}$ & $\mathbf{7 4 , 1 7 \%}$ \\
\hline
\end{tabular}

Hasil observasi aktivitas mengajar dan aktivitas peserta didik pada Siklus II diperolah data sebagai berikut:

\begin{tabular}{|l|c|c|}
\hline $\begin{array}{c}\text { Hasil } \\
\text { Observasi }\end{array}$ & $\begin{array}{c}\text { Observasi } \\
\text { Aktivitas } \\
\text { Mengajar }\end{array}$ & $\begin{array}{c}\text { Aktivitas } \\
\text { Peserta Didik }\end{array}$ \\
\hline Pertemuan 1 & $81,67 \%$ & $88,33 \%$ \\
\hline Pertemuan 2 & $90 \%$ & $91,67 \%$ \\
\hline Persentase & $\mathbf{8 5 , 8 3 \%}$ & $\mathbf{8 9 , 9 \%}$ \\
\hline
\end{tabular}

Penelitian dilaksanakan di SD Negeri Kasatriyan, subjek dalam penelitian ini adalah peserta didik kelas $\mathrm{V}$ yang 
berjumlah 15 peserta didik, terdiri dari 10 peserta didik laki-laki dan 5 peserta didik perempuan pada materi organ pencernaan. Berdasarkan hasil penelitian yang sudah dilakukan dalam upaya meningkatkan hasil belajar peserta didik pada Tema 3 Subtema 1 bagaimana tubuh mengolah makanan mata pelajaran IPA dengan menggunakan media kartu tempel kelas V Sekolah Dasar Negeri Kasatriyan sudah terlaksana dengan sangat baik dan terbukti berhasil. Media kartu tempel adalah sebuah alat atau media belajar yang dirancang oleh peneliti untuk membantu mempermudah belajar dalam pembelajaran tematik, menjadikan peserta didik aktif dalam kegaiatan pembelajaran. Dengan menggunakan media pembelajaran kartu tempel, peserta didik akan terlibat secara langsung dalam kegiatan pembelajaran.

Sebelum dilaksanakan tindakan perbaikan selama proses pembelajaran IPA, peserta didik masih menganggap bahwa mata pelajaran IPA merupakan pembelajaran yang sulit untuk dihafal sehingga menjadikan hasil belajar peserta didik rendah. Peserta didik juga kurang aktif dalam kegiatan diskusi kelompok dan tanya jawab selama proses pembelajaran, sehingga aktivitas belajar peserta didik masih kurang.

Setelah dilakukan perbaikan pembelajaran dengan menggunakan media kartu tempel, antusias peserta didik tinggi dan lebih bersemangat mengikuti pelajaran dengan guru. Antusias peserta didik tersebut menunjukkan bahwa ketertarikan peserta didik pada media kartu tempel sangat tinggi. Penggunaan media kartu tempel yang menarik mampu memberikan kesan tersendiri pada peserta didik, yaitu peserta didik dapat mudah menghafal materi yang biasanya susah untuk dihafalkan. Media kartu tempel yang diterapkan oleh peneliti menunjukkan adanya peningkatan aktivitas dan hasil belajar peserta didik pada mata pelajaran IPA. Hal tersebut dibuktikan dengan hasil observasi aktivitas guru dalam mengajar pada siklus I sebesar $72,5 \%$ meningkat pada siklus II menjadi $85,83 \%$. Pada aktivitas belajar peserta didik siklus I sebesar 74,16\% meningkat pada siklus II menjadi $89,9 \%$. Pada siklus I hasil observasi aktivitas belajar peserta didik yaitu pada pertemuan 1 sebesar $71,67 \%$ dan pertemuan 2 sebesar $76,67 \%$. Meningkat pada siklus II pertemuan 1 menjadi $88,33 \%$ dan pada pertemuan 2 meningkat lagi menjadi $91,67 \%$.

Aktivitas guru dan aktivitas belajar peserta didik memiliki pengaruh pada hasil belajar peserta didik pada mata pelajaran IPA materi organ pencernaan. Peningkatan hasil belajar peserta didik dilihat sebelum dilakukannya tindakan penelitian. Sebelum dilakukan tindakan penelitian hasil belajar peserta didik masih sangat rendah yang dibuktikan dengan nilai ulangan harian peserta didik. Pada kondisi awal nilai ulangan harian yang sudah mencapai KKM hanya 3 dari 15 peserta didik atau sejumlah $20 \%$. Sedangkan 12 orang lainnya belum mencapai KKM atau sejumlah $80 \%$. Berdasarkan data awal (pretest) dengan nilai rata-rata 66 dengan persentase ketuntasan belajar klasikal sebesar 33\% . Setelah dilaksanakan pembelajaran dengan media kartu tempel hasil belajar peserta didik mengalami peningkatan, dari siklus I ketuntasan belajar peserta 
didik hanya 10 orang dari 15 peserta didik atau $67 \%$, sedangkan pada siklus II jumlah peserta didik yang tuntas 13 orang atau $87 \%$.

Berdasarkan pembahasan di atas dapat disimpulkan bahwa penggunaan media kartu tempel dapat meningkatkan hasil belajar peserta didik pada Tema 3 Subtema 1 Bagaimana Tubuh Mengolah Makanan mata pelajaran IPA materi organ pencernaan kelas V SD Negeri Kasatriyan Tahun Pelajaran 2019/2020. Tampubolon (2014: 55), menjelaskan indikator keberhasilan hasil belajar secara klasikal minimal $75 \%$ dari jumlah siswa yang mencapai KKM yang ditetapkan. Pembelajaran IPA dengan media kartu tempel dapat meningkatkan hasil belajar peserta didik, dengan indikator peserta didik kelas V SD Negeri Kasatriyan mengalami ketuntasan belajar individual dengan nilai $\geq 75$ atau mengalami nilai ketuntasan belajar klasikal sebesar 75\%.

\section{SIMPULAN}

Berdasarkan hasil penelitian dan pembahasan yang telah dilakukan maka dapat disimpulkan bahwa penerapan media kartu tempel dapat meningkatkan hasil belajar peserta didik kelas V Sekolah Dasar Negeri Kasatriyan Kecamatan Wates Kabupaten Kulon Progo Tahun Pelajaran 2019/2020 pada tema 3 subtema 1 bagaimana tubuh mengolah makanan mata pelajaran IPA materi organ pencernaan. Peningkatan hasil belajar dapat terjadi karena adanya peningkatan aktivitas mengajar guru dan aktivitas peserta didik dengan menggunakan media pembelajaran kartu tempel pada kegiatan pembelajaran yang mampu meningkatkan hasil belajar peserta didik.

\section{DAFTAR PUSTAKA}

Aly, Abdullah \& Eny Rahma. (2009). Ilmu Alamiah Dasar. Jakarta: Bumi Aksara.

Daryanto. (2011). Penelitian Tindakan Kelas dan Penelitian Tindakan Sekolah. Yogyakarta: Gava Media.

Hosnan, M. (2014). Pendekatan Saintifik dan Kontekstual Dalam Pembelajaran Abad 21. Bogor: Ghalia Indonesia.

Jannah, Miftahul \& Hasmawati. (2017). Penggunaan Media Kartu Bergambar dalam Keterampilan Menulis Karangan Sederhana Bahasa Jerman Siswa Kelas XI IPS Sma Negeri 1 Segeri Kabupaten Pangkep. Jurnal Pendidikan Bahasa Asing dan Sastra, 1(1), 12-17. Diakses pada tanggal 4 Desember 2019 pukul 20.06 WIB dari http://ojs.unm.ac.id/eralingua/article /view/2985/1625

Masturi, dkk. (2014). Pengaruh Penggunaan Media Kartu Bergambar Terhadap Kemampuan Mendeskripsikan Daur Hidup Organisme Dilihat Dari Tingkat Kemandirian Belajar Siswa Di SD 5 Dersalam Kudus. Jurnal, 7(1), 39-44. Diakses pada tanggal 16 Desember 2019 pukul 17.46 WIB dari http://media.neliti.com/media/public ations/23229-ID-pengaruh pengguna an-media-kartu-bergambar terhadap -kemampuan-mendeskripsikan dau. pdf

Rusdiana. (2018). Penilaian Autentik. Bandung: Pustaka Setia.

Susanto, Ahmad. (2013). Teori Belajar dan Pembelajaran di Sekolah Dasar. Jakarta: Prenadamedia Group.

Tampubolon, M Saur. (2014). Penelitian Tindakan Kelas Sebagai Pengembangan Profesi Pendidik dan Keilmuan. Jakarta: Erlangga. 
Wena, Made. (2011). Strategi Pembelajaran Inovatif Kontemporer (Suatu Tinjauan Konseptual Operasional). Jakarta: Bumi Aksara. 